\title{
AN ANALYSIS OF DIVISIONAL INVESTMENT POLICIES
}

Hyun-Han Shin

René M. Stulz

Working Paper 5639

\author{
NATIONAL BUREAU OF ECONOMIC RESEARCH \\ 1050 Massachusetts Avenue \\ Cambridge, MA 02138 \\ June 1996
}

We are grateful to Judy Chevalier, Gene Fama, Steve Kaplan, Owen Lamont, Tim Opler, Jay Ritter, Andrei Shleifer, Ralph Walkling, Jeff Zwiebel, participants at the NBER Corporate Finance Spring 1996 Group Meeting and at seminars at the Ohio State University, the University of Chicago, and Stanford University for useful comments. This paper is part of NBER's research program in Corporate Finance. Any opinions expressed are those of the authors and not those of the National Bureau of Economic Research.

(C) 1996 by Hyun-Han Shin and René M. Stulz. All rights reserved. Short sections of text, not to exceed two paragraphs, may be quoted without explicit permission provided that full credit, including (C) notice, is given to the source. 
NBER Working Paper 5639

June 1996

\title{
AN ANALYSIS OF DIVISIONAL INVESTMENT POLICIES
}

\begin{abstract}
This paper investigates the divisional investment policies of diversified firms. We find that investment of the smallest division of diversified firms is significantly related to the cash flow of the other segments. We then show that the smallest division's investment is more sensitive to the cash flow of the other divisions for firms where one expects aggregate investment to be related to cash flow also, namely low q firms and firms with high leverage. This and other evidence we provide is consistent with what we call the bureaucratic rigidity hypothesis. This hypothesis states that relative allocations of investment funds in diversified firms are sticky. We fail to find support for the view that diversified firms allocate more funds to divisions in industries with better investment opportunities.
\end{abstract}

Hyun-Han Shin

Department of Finance

Lundquist College of Business

University of Oregon

Eugene, OR 97403-1208
René M. Stulz

Department of Finance Ohio State University 314 Hagerty

1775 College Road

Columbus, OH 43210 and NBER 


\section{Introduction.}

Does it matter for a division's investment policy whether it is part of a highly diversified firm, a moderately diversified firm, or is a stand-alone firm? The view that diversification creates value is often based on the idea that being part of a diversified firm makes it possible for a division to invest without the impediments from capital market imperfections. ${ }^{1}$ We call this the efficient internal capital markets hypothesis. The alternative view that diversified firms invest less efficiently is generally associated with the proposition that, because of their additional layers of management, they find it difficult to take advantage of good investment opportunities at the division level and fail to decrease aggressively investment in divisions that have poor investment opportunities. We call this hypothesis the bureaucratic rigidity hypothesis. In this paper, we first show that divisions of diversified firms invest differently than otherwise comparable stand-alone firms and then explore why this is so.

Even though the various views of diversified firms lead to the conclusion that investment differs between a division of a diversified firm and an otherwise comparable stand-alone firm, there is little evidence on how investment policies differ between diversified firms and specialized firms. Most of the evidence on the investment policies of diversified firms is indirect and demonstrates that diversified firms are valued less than comparable portfolios of specialized firms. ${ }^{2}$ One exception is Lamont (1996), who reports that diversified oil companies reduced investment in non-oil divisions when they faced decreased oil revenues. Lamont's (1996) evidence shows that division-level investment of diversified oil companies depends on other variables than the investment

\footnotetext{
1 See, for instance, Williamson (1975). Stein (1996) provides a model where diversification increases efficiency of firms that are liquidity-constrained because management allocates more funds to the more efficient divisions.

2 See, for instance, Berger and Ofek (1995), Comment and Jarrell (1995) and Lang and Stulz (1994).
} 
of comparable single-segment firms, but his research is not focused on trying to understand how investment in diversified firms is different, but rather to provide evidence on the existence of liquidity constraints.

The literature on investment policy at the firm level has documented a strong relation between a firm's investment and its cash flow. ${ }^{3}$ One explanation for this result is that external finance is expensive relative to internal finance. This can be because of information asymmetries and/or because of agency costs. With this explanation, firms that find it most expensive to access outside funds finance investment mostly through their cash flow. Diversification breaks the link between a division's cash flow and its investment even if the firm finds outside funds expensive. A diversified firm can use the cash flow from one division to finance investment in another division. We therefore investigate first whether the link between a division's cash flow and its investment is weaker than the link between a firm's cash flow and its investment and whether there is a relation between the investment of a division and the cash flow of other divisions. Finding such a relation would be evidence that the internal capital market plays an important role in diversified firms.

In our investigation, we consider separately small and large divisions. The largest division of a firm should have an investment policy fairly similar to the investment policy of a stand-alone firm since it typically represents a large part of the diversified firm. In contrast, we would expect the investment of the smallest division to be less related to its own cash flow than it would be if the division was a stand-alone firm. We find strong evidence supportive of this view. Investment of the smallest division does not depend on the smallest division's cash flow when the firm is highly

\footnotetext{
${ }^{3}$ This literature is reviewed in Bernanke, Gertner and Gilchrist (1994) and Hubbard (1995). Kaplan and Zingales (1995) provide a critical perspective on this literature.
} 
diversified, but depends significantly on the cash flow of the other divisions. In other words, if the other segments have unexpectedly high cash flow, this increases the investment of a small segment more than if that small segment itself has an unexpectedly high cash flow. In contrast, the investment of the largest division depends significantly on its cash flow and seems unaffected by the cash flow of the other divisions.

Establishing that the investment of small divisions depends significantly on the cash flow of other divisions shows that the internal capital market of diversified firms is important. It does not establish whether the role of this capital market is positive or negative. We then show, however, that a division in a diversified firm may invest less than its industry because the other divisions are doing poorly or more because its other divisions are doing well. Such evidence suggests that the internal capital market can lead firms to underinvest or overinvest because of the performance of other divisions. We explore three hypotheses of the investment policies of diversified firms and investigate to which extent they can explain such results:

1. The bureaucratic rigidity hypothesis. It is often argued that diversified firms are inefficient because the added layers of management make them unresponsive to new investment opportunities at the division level. This argument suggests that intra-firm capital allocations are sticky, in that each division's fraction of the capital budget is insensitive to its investment opportunities. If a firm's aggregate cash flow is an important determinant of its capital budget, there should be a relation between a division's investment and the firm's cash flow irrespective of why there is a relation between aggregate cash flow and the capital budget. Consequently, a division's investment is related to the cash flow of other divisions. With this hypothesis, 
one would expect the relation between a division's investment and other divisions' cash flow to be weak for those firms where one does not expect investment to be sensitive to cash flow. Firms with low leverage and/or highly valued investment opportunities can borrow at low cost, so that one would not expect their investment to be as sensitive to cash flow as the investment of highly levered firms and firms with poor investment opportunities. We find that the dependence of a division's investment on the cash flow of other divisions is much weaker for firms with valuable investment opportunities and/or low leverage. Presumably, bureaucratic rigidity would become more of an issue as the firm's degree of diversification grows. Consequently, we would expect that the cash flow of other divisions should become a more important determinant of a division's investment as the number of segments increases. We find that it is indeed so.

2. The efficient internal capital market hypothesis. If management wants the firm to grow or if it pursues positive net present value projects, one would expect it to grow divisions that have good investment opportunities and shrink divisions that have poor investment opportunities. If outside funds are expensive because the firm is highly levered and/or has poor investment opportunities, the firm relies mostly on its cash flow to finance investment and one would expect the other divisions to benefit if the largest division has poor investment opportunities but large cash flow. The smallest division should grow especially if it is in an industry that has good growth opportunities. We split the sample according to above-median and below-median investment opportunities and cash flow of the largest segment. We fail to find evidence supportive of the view that the firm directs more resources towards its smallest division if it is in an industry with good growth opportunities. 
3. The free cash flow hypothesis. Jensen's (1986) free cash flow hypothesis implies that firms overinvest rather than pay out cash flows to investors. If a firm's core business has poor growth opportunities, management will seek growth opportunities through diversification. One would therefore expect management to grow the smallest division if the firm's core business has poor growth opportunities but generates cash flow that can be re-invested. This behavior relies on the existence of an internal capital market. With the free cash flow hypothesis, shareholders may well be better off with diversification than without. If management could not diversify, it might invest more in the core business that has poorer investment opportunities than other segments! The direct prediction of the free cash flow hypothesis is that the firm will invest more in noncore segments if its core business has poor growth opportunities but generates cash flow that can be invested. We find that investment of the smallest segment depends more on the cash flow of the other segments when the firm has a low $q$, which is consistent with the free cash flow hypothesis but also with the bureaucracy rigidity hypothesis. To provide more support for the free cash flow hypothesis, we should also find that the smallest segment grows more (less) when the largest division has high (low) cash flow and poor (good) growth opportunities. We find that the investment of the smallest segment does not depend on the cash flow of the other segments when the largest segment has good growth opportunities and low cash flow. However, we fail to find convincing evidence that the smallest segment grows more when the largest segment has poor growth opportunities but high cash flow.

The paper proceeds as follows. In section 2, we present our data. In section 3 , we investigate the relation between investment of the smallest (largest) division and cash flow of the largest (smallest) division and show that our results are not explained 
by mismeasurement. In section 4 , we investigate the bureaucratic rigidity, the efficient internal capital market, and the free cash flow hypotheses. We conclude in section 5.

\section{Section 2. The data.}

All our data comes from COMPUSTAT. The Business Information file of COMPUSTAT provides information for firms disaggregated for up to 10 different industry segments. FASB-SFAS No. 14 and SEC Regulation S-K require firms to report segment information for fiscal years ending after December 15, 1977. SFAS No. 14 defines an industry segment as "A component of an enterprise engaged in providing a product or service, or a group of related products or services primarily to unaffiliated customers (i.e., customers outside the enterprise) for a profit." Firms must report information for segments that represent $10 \%$ or more of the consolidated sales. The files have information available for some firms for 1976 and 1977, though firms did not have to report for these years if their fiscal year ends December 15 or earlier. The files contain 110,238 segment-year records for the period from 1976 to 1992 . We do not use the 1976 and 1977 years since reporting for these years is not uniform. Since we use lagged variables in our regressions, omitting 1976 and 1977 means that we can report results for investment from 1980 onwards. From 1980 on, we have 96,228 segment-years. For our analysis, we use the active and research files of COMPUSTAT, so that our sample includes the firms that were subsequently delisted from COMPUSTAT because of mergers, bankruptcies, liquidations, and so on.

Compared to the other databases used in the literature, the one used here has both strengths and weaknesses. In an earlier study measuring the degree of diversification of firms, Ravenscraft and Scherer (1987) use data from the 1975 Line of Business 
sample of the Federal Trade Commission. To construct this sample, the FTC collected sales and other financial variables from 471 large corporations. The data classify sales using 262 manufactured product categories, but allows firms to aggregate sales from different categories into one in cases where sales in one category are small. Wernerfelt and Montgomery (1988), Lichtenberg (1992) and Liebeskind and Opler (1992) use census data on plants and measured diversification in terms of numbers of different SIC codes for plants. Lichtenberg (1992) also uses the Compustat SIC File, which reports up to $90 \mathrm{SIC}$ codes per company. More recently, Berger and Ofek (1995), Comment and Jarrell (1995) and Lang and Stulz (1994) use the same database we do. For this study, none of the alternative databases would be suitable because they do not provide time series of investment. However, the COMPUSTAT database reports information for up to ten segments only, does not have private firms and, as argued by Lichtenberg (1991) and others, is subject to possible reporting biases.

For each segment, we collect six variables: net sales, operating profit (loss), depreciation, capital expenditures, identifiable total assets, and SIC code. We exclude segments which do not contain complete information on these variables. Doing so reduces the sample to 52,700 segment-years. Throughout the paper, we focus on the largest and smallest divisions. This yields 35,488 segment-years corresponding to 17,744 firm-years. An important difficulty in using this data is that firms reorganize their segments over time. To prevent such reorganizations from affecting our conclusions, we eliminate segment-years where any of the five ratios used in our analysis exceeds one. The ratios are the current and lagged value of net capital expenditures over the previous year's total assets, sales change over the previous year's sales, cash flow to total assets, and finally, other segments' cash flow divided by total assets of these segments. Cash flow is defined as operating profit (loss) plus depreciation. The ratios 
we use are dictated to us by data availability. After excluding outliers, we end up with 16,476 firm-year records corresponding to 3,000 different firms.

Table 1 provides descriptive statistics for our dataset. In panel A, we report the number of firms each year per number of segments. The number of firms exceeds 900 each year. Throughout the paper, we emphasize results for the largest and the smallest divisions of each firm. Consequently, in table 1, we provide the means and medians of the ratios we use in the paper for both the largest and smallest divisions. Note that the number of segments falls over time. Although some of that fall may be due to changes in reporting practices, most of it is due to the decrease of firm-level diversification during the 1980s. Evidence consistent with this interpretation is that studies using different databases document a decrease in diversification also. ${ }^{4}$

The table does not indicate the industry of the segments. The SIC code of the largest segment is also generally the main SIC code of a firm. Consequently, the SIC code distribution of the largest segment is similar to the main SIC code distribution of the Compustat files. The one-digit SIC code with the largest number of smallest segments is 3 which has 5,794 smallest segment-years. That SIC code has more than twice the number of segment-years than the SIC code with the next largest number of smallest segments, which is code 2 . That code has 2,414 segment-years. The other SIC codes have between 1,000 and 2,000 smallest segment-years except for SIC code 1 which has only 523 smallest segment-years. Since we are trying to understand the investment policies of diversified firms, it is important for us to include segments from all one digit SIC codes. For instance, it could be that firms diversify away from their one

\footnotetext{
${ }^{4}$ Liebeskind and Opler (1994) use the Trinet database and document a decrease in firm diversification also.
} 
Table 1. Descriptive statistics for initial sample dataset.

All data comes from the Business Information file of COMPUSTAT. We use all firms from 1980 to 1992 for which we can compute the ratios that are used in our investment equations. Panel A report the number of firms each year per number of segments. Panel $B$ reports the means and medians of the ratios for both the largest and smallest divisions.

Panel A.

\begin{tabular}{|c|c|c|c|c|c|c|c|c|c|c|}
\hline \multirow[b]{2}{*}{ Frequency } & \multicolumn{9}{|c|}{ Number of segments } & \multirow[b]{2}{*}{ Tota } \\
\hline & 2 & 3 & 4 & 5 & 6 & 7 & 8 & 9 & 10 & \\
\hline 80 & 526 & 503 & 321 & 159 & 74 & 23 & 15 & 4 & 7 & 1632 \\
\hline 81 & 531 & 459 & 308 & 152 & 63 & 27 & 16 & 5 & 2 & 1563 \\
\hline 82 & 516 & 422 & 290 & 144 & 60 & 25 & 11 & 4 & 3 & 1475 \\
\hline 83 & 526 & 422 & 292 & 133 & 57 & 23 & 11 & 1 & 4 & 1469 \\
\hline 84 & 477 & 418 & 273 & 120 & 38 & 19 & 9 & 4 & 3 & 1361 \\
\hline 85 & 436 & 391 & 232 & 100 & 34 & 17 & 6 & 5 & 2 & 1223 \\
\hline 86 & 471 & 352 & 212 & 81 & 36 & 15 & 6 & 1 & 1 & 1175 \\
\hline 87 & 432 & 350 & 211 & 80 & 36 & 12 & 7 & 3 & 2 & 1133 \\
\hline 88 & 431 & 336 & 192 & 82 & 33 & 18 & 4 & 2 & 3 & 1101 \\
\hline 89 & 427 & 335 & 193 & 72 & 36 & 19 & 6 & 1 & 3 & 1092 \\
\hline 90 & 449 & 342 & 192 & 75 & 45 & 19 & 5 & 1 & 4 & 1132 \\
\hline 91 & 484 & 341 & 212 & 84 & 34 & 19 & 2 & 3 & 4 & 1183 \\
\hline 92 & 365 & 285 & 172 & 69 & 30 & 8 & 3 & 2 & 3 & 937 \\
\hline Total & 6071 & 4956 & 3100 & 1351 & 576 & 244 & 101 & 36 & 41 & 16476 \\
\hline
\end{tabular}

Panel B.

\begin{tabular}{rccccc}
\hline & $\begin{array}{c}\text { net capital } \\
\text { expenditure/ } \\
\text { own segment's } \\
\text { assets }\end{array}$ & $\begin{array}{c}\text { net capital } \\
\text { expendituref } \\
\text { own segment's } \\
\text { assets }\end{array}$ & $\begin{array}{c}\text { sales change/ } \\
\text { net sales }\end{array}$ & $\begin{array}{c}\text { own segment's } \\
\text { cash flow/ own } \\
\text { segment's } \\
\text { assets }\end{array}$ & $\begin{array}{c}\text { other } \\
\text { segments' } \\
\text { cash flow/ } \\
\text { other } \\
\text { segments' } \\
\text { assets }\end{array}$ \\
\cline { 2 - 6 } & 0.03 & 0.04 & 0.07 & 0.17 & 0.17 \\
$99 \%$ & 0.44 & 0.49 & 0.82 & 0.72 & 0.62 \\
$95 \%$ & 0.19 & 0.22 & 0.51 & 0.47 & 0.41 \\
$90 \%$ & 0.12 & 0.13 & 0.36 & 0.37 & 0.33 \\
Median & 0.01 & 0.01 & 0.07 & 0.16 & 0.16 \\
$10 \%$ & -0.03 & -0.03 & -0.20 & 0.00 & 0.03 \\
$5 \%$ & -0.05 & -0.05 & -0.34 & -0.08 & -0.02 \\
$1 \%$ & -0.14 & -0.12 & -0.72 & -0.37 & -0.25
\end{tabular}


digit SIC code, so that we might miss this if we focused on only a few one digit SIC codes.

\section{Section 3. Investment policies of the smallest and largest segments.}

In table 2, we report estimates of investment equations for the smallest and largest segments. Although we do not report these regressions in the paper, we also estimated all our regressions excluding the smallest segment when its assets represent more than $20 \%$ of the firm's total assets. None of our conclusions are affected by using such a threshold. In the equations of table 2 , we regress the ratio of net capital expenditures in period $t+1$ to the segment's assets at the end of period $t$ on (a) the lagged value of that ratio, (b) the growth in sales of the segment from period $t-1$ to $t$ (c) the segment's cash flow in t normalized by the segment's total assets at the end of period $t$, and (d) the sum of the cash flows of the other segments in t normalized by the sum of their assets at the end of period t. We cannot use a Tobin's q proxy for the segment as an explanatory variable because no data is available to construct it. Since the sample period we use corresponds to years that differ in tax regimes and stages of the business cycle, we add a dummy variable for each year to the regression. We do not report these dummy variables in the tables. All regressions in the paper use White's adjustment for heteroskedasticity. In some of the regressions reported later, we also control for industry.

Panel $A$ uses all the firms in our sample. In all four regressions reported in that panel, the most significant variable is the lagged value of the dependent variable. We find that if we use all the firms that have at least two segments, all variables are significant and have a positive coefficient, including the other segments' cash flow. 
However, when we restrict the sample to the firms that have five segments or more, the results differ substantially between small and large segments. For the smallest segment, neither past growth in sales nor the segment's cash flow are significant, but other segments' cash flow has a positive significant coefficient. Looking at the size of the coefficients, the coefficient on other segments' cash flow is twice as large as the coefficient on the segment's cash flow. From this regression, there is no evidence that proxies for the segment's performance or investment opportunity set such as growth of sales or cash flow matter for the segment's capital expenditures. In contrast, for the largest segment of firms with five segments or more, the coefficient on other cash flows is not significant and its point estimate shows no economic significance. The coefficient on the segment's own cash flow is more than three times the size of the coefficient on the segment's cash flow in the comparable regression for the smallest segment and has a t-statistic of 4.30 .

The sample used to obtain panel $A$ includes many small firms, so it could be argued that these firms are not informative for the investment policies of the large diversified firms which are the focus of most analyses of the benefits and costs of diversification. It is also possible that the data is not as reliable for these firms. This could be especially the case for data on the smallest segment of small firms. We therefore restrict our sample in the following to firms with sales of at least one billion dollars in 1977 dollars each year in which they enter the sample. This insures that the smallest segment is fairly large. The book value of the assets of the smallest segment has a mean of $\$ 970$ million and a median of $\$ 339$ million. This contrasts with the book value of the assets of the largest segment which has a mean of $\$ 4,411$ million and a median of $\$ 1,633$ million. This sample has many fewer observations than the sample of panel A. The estimated equations are reported in panel B of table 2 . For the firms with 
Table 2. Estimates of investment equations for small and large segments.

Panel A uses all the firms in our sample from 1980 to 1992 for which we can compute the ratios used in our regressions. Panel $B$ uses only the firms in the sample of panel $A$ with sales of at least one billion dollars in 1977 dollars each year in which they enter the sample. To identify the timing of the observation of the variables, we use periods 1,0 and -1 . The dependent variable is the segment's net capital expenditures in period 1 divided by the book value of the segment's assets at the end of period 0 . $t$-statistics are in parentheses.

Panel A. All firms.

\begin{tabular}{|c|c|c|c|c|c|c|}
\hline \multirow{6}{*}{$\begin{array}{l}\text { net capital expenditure (0) / own } \\
\text { segment's assets }(-1) \\
\text { sales change }(0) / \text { net sales }(-1) \\
\text { own segment's cashflow }(0) \text { / own } \\
\text { segment's assets }(0) \\
\text { other segments' cashflow }(0) / \\
\text { other segments' assets }(0)\end{array}$} & \multicolumn{3}{|c|}{ For the smallest segments only } & \multicolumn{3}{|c|}{ For the largest segments only } \\
\hline & 2 or more & \multicolumn{2}{|c|}{5 or more } & 2 or more & \multicolumn{2}{|c|}{5 or more } \\
\hline & $0.3667(24.88)$ & 0.2906 & (6.48) & $0.4064(21.78)$ & 0.5073 & (10.39) \\
\hline & 0.0130 & 0.0068 & $(0.76)$ & 0.0181 & 0.0175 & (1.52) \\
\hline & 0.0306 & 0.0207 & (1.11) & 0.0467 & 0.0654 & (4.30) \\
\hline & 0.0205 & 0.0444 & (2.52) & 0.0193 & 0.0008 & $(0.05)$ \\
\hline Adj-R-sq & 0.19 & 0.13 & & 0.23 & 0.32 & \\
\hline Obs. & 16476 & 2349 & & 16476 & 2349 & \\
\hline
\end{tabular}

Panel B. Firms with sales above $\$ 1$ billion in 1977 dollars.

\begin{tabular}{|c|c|c|c|c|c|c|c|}
\hline \multirow[b]{3}{*}{$\begin{array}{l}\text { net capital expenditure }(0) \text { / own } \\
\text { segment's assets }(-1)\end{array}$} & \multicolumn{3}{|c|}{ For the smallest segments only } & \multicolumn{4}{|c|}{ For the largest segments only } \\
\hline & 2 or more & \multicolumn{2}{|c|}{5 or more } & \multicolumn{2}{|c|}{2 or more } & \multicolumn{2}{|c|}{5 or more } \\
\hline & 0.3951 & 0.2985 & $(3.87)$ & 0.5601 & $(9.67)$ & 0.5445 & $(8.09)$ \\
\hline sales change $(0) /$ net sales $(-1)$ & 0.0139 & 0.0187 & $(1.50)$ & 0.0114 & (1.86) & 0.0206 & (1.98) \\
\hline $\begin{array}{l}\text { own segment's cashflow }(0) \text { / own } \\
\text { segment's assets }(0)\end{array}$ & 0.0416 & 0.0201 & (1.36) & 0.0653 & $(6.04)$ & 0.0731 & $(5.84)$ \\
\hline $\begin{array}{l}\text { other segment's cashflow }(0) \text { I } \\
\text { other segment's assets }(0)\end{array}$ & 0.0426 & 0.0645 & (2.39) & 0.0141 & $(1.30)$ & -0.0059 & $(-0.29)$ \\
\hline Adj-R-sq & 0.24 & 0.18 & & 0.39 & & 0.45 & \\
\hline Obs. & 3329 & 1084 & & 3329 & & 1084 & \\
\hline
\end{tabular}


five segments or more, there is no difference worth reporting between the two panels. For the firms with two segments or more, the main difference between the two panels is that now other segments' cash flow is no longer significant for the largest segment. Hence, for large firms, the differences between the investment policies of the smallest and largest segments seem magnified: the largest segment does not seem to invest more when the other segments do well, in contrast to the smallest segment.

The sample in table 2 contains firms whose segments are in similar industries as well as firms whose segments are in quite different industries. It could be, therefore, that other segments' cash flow is significant in our regressions simply because it happens that for the smallest segment the firm has other, larger segments, in very similar industries. In this case, other segments' cash flow might be a better proxy for the smallest segments' investment opportunities because the larger other segment in a closely related industry might have more stable cash flows. We therefore estimate the regressions of table 2 using as other segments' cash flows only the segments that have different 2-digit SIC codes from the smallest segment. These regressions are reproduced in table 3 . The results of table 3 are similar to those of table 2 . Therefore, it is difficult to argue that our results are due to a lack of diversification within firms because other segments are somehow too similar to the smallest segment. The approach used here does not allow us to take into account vertical integration, however.

The results shown so far make no adjustment for industries. Taking into account the industry in which a segment operates allows us to investigate whether a segment's investment relative to its industry is greater or smaller depending on how the other segments of the diversified firm are doing. In the regressions reported in table 4 , we subtract the industry median from all variables except other segments' cash flow. 
Table 3. Estimates of investment equations using as other segments' cash flows only those that have different 2-digit SIC codes from the smallest segment.

The sample comprises all firms with sales of at least $\$ 1$ billion in 1977 dollars for which the variables could be computed using the Compustat Business Information files excluding 1976 and 1977 and excluding the firms where one or more of the accounting ratios used in the regressions exceed one. To identify the timing of the observation of the variables, we use periods 1,0 and -1 . The dependent variable is the segment's net capital expenditures in period 1 divided by the book value of the segment's assets at the end of period 0 . $t$-statistics are in parentheses.

net capital expenditure (0)/ own segment's assets $(-1)$

For the smallest segments only

sales change (0)/ net sales $(-1)$ own segment's cash flow (0) I own segment's assets (0) other segments' cash flow (0) I other segments' assets (0)

\begin{tabular}{c}
\hline For the \\
\hline 2 or m \\
\hline 0.3764 \\
0.0142 \\
0.0418 \\
0.0379 \\
0.23 \\
2968
\end{tabular}

$\begin{array}{lll}(8.17) \quad 0.2951 \quad(3.80) & \end{array}$

For the largest segments only

Adj-R-sq

0.23
2968

$\begin{array}{lll}(2.09) & 0.0192 \quad(1.52)\end{array}$

$\begin{array}{llll}0.5461 & (8.89) & 0.5426 & (8.01)\end{array}$

$0.0102(1.56)-0.0208(1.95)$

(5.21) $0.0194 \quad(1.29)$

0.0681

(5.93)

0.0744

(3.50) $0.0572 \quad(2.40)$

0.0135

(1.49)

$0.0000 \quad(0.00)$

Obs. 
Table 4. Estimates of industry-adjusted investment equations.

The sample comprises all firms with sales of at least $\$ 1$ billion in 1977 dollars for which the variables could be computed using the Compustat Business Information files excluding 1976 and 1977 and excluding the firms where one or more of the accounting ratios used in the regressions exceed one. The industry median is subtracted from all variables except other segments' cash flows. Industry is defined by the 2-digit SIC code. To identify the timing of the observation of the variables, we use periods 1,0 and -1 . The dependent variable is the segment's net capital expenditures in period 1 divided by the book value of the segment's assets at the end of period 0 . t-statistics are in parentheses.

net capital expenditure (0)/ own segment's assets $(-1)$ For the smallest segments only sales change (0)/ net sales (-1) own segment's cash flow (0) I own segment's assets (0) other segments' cash flow (0)/ other segment's assets ( 0 )

\begin{tabular}{ccccc}
\multicolumn{2}{c}{ For the smallest segments only } \\
\hline 2 or more & \multicolumn{3}{c}{5 or more } \\
\hline 0.3694 & $(8.46)$ & 0.2977 & $(3.75)$ \\
0.0094 & $(1.54)$ & 0.0096 & $(0.85)$ \\
0.0397 & $(5.30)$ & 0.0126 & $(0.90)$ \\
0.0482 & $(4.47)$ & 0.0721 & $(2.64)$
\end{tabular}

\begin{tabular}{ccccc}
\hline \multicolumn{4}{c}{ For the largest segments only } \\
\hline \multicolumn{3}{c}{ 2 or more } & \multicolumn{3}{c}{5 or more } \\
\hline 0.5216 & $(8.88)$ & 0.5482 & $(7.86)$ \\
0.0045 & $(0.56)$ & 0.0134 & $(1.00)$ \\
0.0559 & $(4.59)$ & 0.0438 & $(2.72)$ \\
0.0220 & $(2.05)$ & -0.0010 & $(0.05)$
\end{tabular}

Adj-R-sq 
Industry is defined by the 2-digit SIC code. The results reported in table 4 are similar to those reported in the earlier tables, but have a slightly different interpretation. These results indicate that the smallest segment invests more relative to its industry when the firm's other segments perform better. These results bear on the issue of the efficiency of investment within diversified firms. For firms with five segments or more, it is apparent that whether the smallest segment in the diversified firm outperforms or underperforms its industry, this has no implication for the segment's ability to invest. Although our results are supportive of the view that the multi-division firm plays an active role in transferring cash flows from some divisions to others, it is not at all clear that this activity is beneficial. In the next section, we therefore investigate three alternative hypotheses of the investment policies of diversified firms and examine whether they can explain our evidence.

How robust is the result that the investment of small divisions in diversified firms depends on the cash flow of other divisions? To examine the robustness of this result, we estimated alternative specifications of the regressions of table 2, used different sample periods, and finally estimated the regressions using samples restricted to one digit SIC codes. We discuss all these estimates in the remainder of this section but do not report them in tables since there are so many of them.

The first alternative specifications of the regressions in table 2 we considered had contemporaneous rather than lagged cash flows and both contemporaneous and lagged cash. These alternative specifications lead to the same qualitative conclusions as the regressions in table 2. If we do not control for past investment and past sales growth as a way to take into account division-specific effects, the coefficient on other cash flow is much larger than the coefficient on own cash flow. However, the coefficient on other cash flow is only significant using a one-tailed test whereas the coefficient on 
own cash flow is both economically and statistically negligible. We also estimated the regressions using gross investment as the dependent variable. This seems to increase the coefficient of own cash flow as well as the coefficient of cash flow of other segments.

Table 2 provides estimates using levels of variables rather than differenced variables. We investigated differenced versions of the specification in table 2 . For the whole sample, we find a strong effect of the contemporaneous change in other divisions' cash flow on the change in investment. The coefficient on the change in other divisions' cash flow is 0.0714 with a t-statistic of 2.61 . There is no positive significant effect of the change in own cash flow on investment. When we focus on firms with five segments or more, neither the change in own cash flow nor the change in other cash flows is significant. The coefficient on other cash flows is 0.0403 with at t-statistic of 0.96 . The coefficient on own cash flow is -0.0090 with a t-statistic of 0.32 . The problem seems to be one of power. Differencing reduces the number of observations. If we consider firms with four segments or more, we almost double the number of observations. For these firms, the coefficient on changes in other segments' cash flow is 0.0908 with a t-statistic of 2.17 . In contrast, the coefficient on own cash flow is negative and insignificant.

The investment regressions reported seem stable through time, but their significance falls some as the sample is divided in two equal subsamples. We estimated the regressions of table 2 over two subperiods: $1980-1985$ and 1986-1992. In those regressions, other cash flow is never significant for the largest segment but is significant at least at the 0.10 level for the smallest segment. Further, own cash flow is always highly significant for the largest segment but is not significant for the smallest segment if it belongs to a firm with five segments or more. Somewhat surprisingly, the 
explanatory power of the regressions is much lower for the smallest segment in the second subperiod. In particular, the $\mathrm{R}^{2}$ of the smallest segment regression when the smallest segment belongs to a firm with five segments or more is only 0.06 for the second subperiod, which is much lower than the value of 0.22 for the first subperiod. Rather than dividing the sample into two subperiods, we also estimated the regressions of table 2 year by year. Doing so, the sample size falls dramatically. Nevertheless, for 9 years out of 14 , the coefficient on other cash flows for the firms with five segments or more exceeds the coefficient on own cash flow for the smallest segment. In addition, the coefficient on own cash flow is never significant but the coefficient on other cash flows is significant for four years at the 0.10 level for a two-tailed test.

We finally considered the issue of whether our results are industry-specific or induced by vertical integration. We estimated our regressions restricting the sample each time to all firms in a one digit SIC code. When we do that, the sample sizes become quite small. We therefore estimated our equations first using all firms rather than only the large firms. When we did that, the coefficient on other cash flows for firms with two or more segments is significant for the smallest segment for SIC codes 2, 3, 4 and 6 . When we consider only the large firms, the same coefficient is significant for the SIC codes $1,2,4$ and 6.

\section{Section 4. What determines the allocation of funds within the multi-division firm?}

So far, we have seen that the smallest division of a multi-division firm invests more when the other divisions have high cash flow, but the investment of the largest division seems insensitive to the cash flow of the other divisions. In this section, we 
attempt to understand whether the evidence is consistent with the bureaucratic rigidity hypothesis, the efficient internal capital market, or the free cash flow hypothesis.

There is considerable evidence on the relation between cash flow and investment. Though it is not clear why this relation exists, there is enough evidence at this point to conclude that this relation is not explained by cash flow acting as a proxy for investment opportunities. In this paper, we do not focus on understanding the relation between cash flow and investment better. Rather, we take this relation as given and use it to investigate the bureaucratic rigidity hypothesis.

It is commonly observed that firms that cut capital expenditures tend to do so through across-the-board cuts in investment budgets. This suggests that the share of the aggregate investment budget accruing to each division is sticky but the size of the investment budget is not. If firms maintain some relation between the size of the investment budget and cash flow, one would then observe a relation between investment at the division level and the firm's cash flow. For small divisions, this implies a relation between the division's investment and the cash flow of other divisions. For large divisions, this relation should exist too. However, the coefficient of other cash flow in the investment equation should be inversely related to the size of the division relative to the firm's size. Hence, this suggests a small coefficient on other cash flow for the large division and a large coefficient on other cash flow for the smallest division. At the same time, one would expect the coefficient on own cash flow to be increasing in the relative size of the division. Our evidence is consistent with these implications of the bureaucratic rigidity hypothesis.

One would expect the relation between cash flow and investment to be less tight for firms that have substantial borrowing capacity. If the relation between cash flow and investment is driven by the cost of external funds, firms with substantial borrowing 
capacity have a lower cost of external funds. One would therefore expect the relation between investment and other cash flow to be much weaker for firms with high debt capacity. To investigate this hypothesis, we divide the sample between firms that have above-median leverage and firms that have below-median leverage. ${ }^{5}$ Leverage is defined as total debt divided by total assets. One would expect other cash flow to be less important for firms with below-median leverage. Table 5 reports the results of regressions for firms with below-median leverage in panel $A$ and for firms with abovemedian leverage in panel $\mathrm{B}$. The results are supportive of our hypothesis. In firms with below-median leverage, the cash flow of other segments has no significant impact on the investment of the smallest segment. In contrast, for the firms with above-median leverage, the coefficient on cash flow of other segments for the investment equation of the smallest segment is significant for both the whole sample and for the sample of firms with at least five divisions. For the largest division, the coefficient of the cash flow of other segments is negative but insignificant for the low leverage firms with two segments or more and negative and significant, at the 0.10 level, for low leverage firms with five segments or more. In contrast, for the high leverage firms, the coefficient on other segments' cash flow is positive and marginally significant for the firms with two segments or more and is positive but insignificant for the firms with five segments or more. Hence, for highly levered firms, there is weak evidence that even the investment of the largest division depends on the cash flow of the other divisions.

Lang, Ofek and Stulz (1995) show that leverage does not appear to impede the growth of firms with valuable investment opportunities. In their paper, investment opportunities are measured by a proxy for Tobin's q. Hence, one would expect that the

\footnotetext{
${ }^{5}$ In the following, whenever we split the sample according to a firm characteristic, we do so on a yearly basis to avoid having a situation where all the firms in a subsample come from the same subperiod.
} 
Table 5. Estimates of investment equations for high and low leverage firms.

The sample comprises all firms with sales of at least \$1 billion in 1977 dollars for which the variables could be computed using the Compustat Business Information files excluding 1976 and 1977 and excluding the firms where one or more of the accounting ratios used in the regressions exceed one. Leverage is defined as the book value of total debt divided by the book value of total assets. Panel $A$ reports estimates of investment equations for firms with below-median leverage. Panel $B$ reports estimates of investment equations for firms with above-median leverage. To identify the timing of the observation of the variables, we use periods 1,0 and -1 . The dependent variable is the segment's net capital expenditures in period 1 divided by the book value of the segment's assets at the end of period 0 . $t$-statistics are in parentheses.

Panel A. Firms with below-median leverage.

\begin{tabular}{|c|c|c|c|c|c|c|c|c|}
\hline \multirow[b]{3}{*}{$\begin{array}{l}\text { net capital expenditure (0) / own } \\
\text { segment's assets }(-1)\end{array}$} & \multicolumn{4}{|c|}{ the smallest segments only } & \multicolumn{4}{|c|}{ the largest segments only } \\
\hline & \multicolumn{2}{|c|}{2 or more } & \multicolumn{2}{|c|}{5 or more } & \multicolumn{2}{|c|}{2 or more } & \multicolumn{2}{|c|}{5 or more } \\
\hline & 0.4047 & $(8.60)$ & 0.3000 & $(4.21)$ & 0.5433 & $(8.01)$ & 0.6272 & $(8.01)$ \\
\hline sales change $(0) /$ net sales $(-1)$ & 0.0123 & $(1.52)$ & -0.0040 & $(-0.29)$ & 0.0301 & (3.31) & 0.0360 & $(2.23)$ \\
\hline $\begin{array}{l}\text { own segment's cash flow }(0) / \\
\text { own segment's assets }(0)\end{array}$ & 0.0261 & $(2.50)$ & 0.0034 & $(0.19)$ & 0.0681 & $(4.14)$ & 0.0410 & $(2.57)$ \\
\hline $\begin{array}{l}\text { other segments' cash flow }(0) \text { / } \\
\text { other segment's assets }(0)\end{array}$ & 0.0208 & $(1.39)$ & 0.0472 & $(1.08)$ & -0.0018 & $(0.10)$ & -0.0485 & $(-1.81)$ \\
\hline Adj-R-sq & 0.22 & & 0.13 & & 0.33 & & 0.58 & \\
\hline Obs. & 1634 & & 467 & & 1634 & & 467 & \\
\hline
\end{tabular}

Panel B. Firms with above-median leverage.

\begin{tabular}{|c|c|c|c|c|c|c|c|c|}
\hline \multirow[b]{3}{*}{$\begin{array}{l}\text { net capital expenditure }(0) \text { / own } \\
\text { segment's assets }(-1)\end{array}$} & \multicolumn{4}{|c|}{ the smallest segments only } & \multicolumn{4}{|c|}{ the largest segments only } \\
\hline & \multicolumn{2}{|c|}{2 or more } & \multicolumn{2}{|c|}{5 or more } & \multicolumn{2}{|c|}{2 or more } & \multicolumn{2}{|c|}{5 or more } \\
\hline & 0.3796 & $(5.42)$ & 0.2963 & (2.33) & 0.5690 & (6.43) & 0.4505 & (4.63) \\
\hline sales change $(0) /$ net sales $(-1)$ & 0.0140 & (1.47) & 0.0331 & (1.76) & -0.0031 & $(0.36)$ & 0.0134 & (1.01) \\
\hline $\begin{array}{l}\text { own segment's cashflow }(0) \text { / own } \\
\text { segment's assets }(0)\end{array}$ & 0.0607 & $(4.76)$ & 0.0279 & (1.19) & 0.0567 & $(4.40)$ & 0.0955 & $(5.17)$ \\
\hline $\begin{array}{l}\text { other segment's cashflow }(0) \text { / } \\
\text { other segment's assets }(0)\end{array}$ & 0.0771 & (3.75) & 0.0668 & $(1.80)$ & 0.0256 & $(1.66)$ & 0.0254 & $(0.73)$ \\
\hline Adj-R-sq & 0.26 & & 0.21 & & 0.44 & & 0.36 & \\
\hline Obs. & 1636 & & 609 & & 1636 & & 609 & \\
\hline
\end{tabular}


relation between other cash flows and investment should be weak for firms with good investment opportunities. In table 6, we divide the sample of high and low leverage firms further according to whether our measure of Tobin's $q$ is above the median or below the median. We use the firm's market value divided by its book value as a measure of Tobin's q (as in Smith and Watts (1992), the precise definition is the ratio of the market value of shares outstanding plus total assets minus book equity and the book value of total assets). We would expect the coefficient on other cash flows to be weakest for firms with low leverage and a high $q$ and to be strongest for the firms with high leverage and a low $q$. We find in panel $A$ of table 6 that for high $q$ firms, the cash flow of other segments does not have a significant positive coefficient for the smallest or the largest segment, whether the firm is highly diversified or not, and whether it has high leverage or not. Surprisingly, the coefficient on the cash flow of other segments has a significant negative coefficient for the largest segment, suggesting that as the other segments do better, the firm effectively imposes a tax on the largest segment. Panel $B$ reports results for low q firms. For these firms, the cash flow of other segments has a significant coefficient in the regression for the smallest segment when the firm has at least two divisions whether the firm has high or low leverage. When we turn to the firms with five divisions or more in panel $B$, the same coefficient has a t-statistic of 2.14 for the firms with low leverage and a t-statistic of 1.30 for the firms with high leverage. It is useful to note, however, that the coefficient on other segments' cash flow for the low q firms with above-median leverage, 0.0708 , is about the same as the coefficient on the same variable in table 5 for firms with above-median leverage, 0.0668. It seems, therefore, that for low q firms the coefficient on other segments' cash flow is large and not significantly different for low leverage low $q$ firms and high leverage low q firms. This suggests that investment opportunities play an important role 
Table 6. Estimates of investment equations for high and low $Q$ firms for firms with high and low leverage.

Panel A reports estimates of investment equations for firms with above-median market-tobook ratio. Panel B reports estimates of investment equations for firms with below-median market-to-book ratio. To identify the timing of the observation of the variables, we use periods 1,0 and -1 . The dependent variable is the segment's net capital expenditures in period 1 divided by the book value of the segment's assets at the end of period 0 . $t$-statistics are in parentheses.

net capital expenditure (0) / own segment's assets $(-1)$

Panel A. High $Q$ firms.

For smallest segments

\begin{tabular}{cccc}
\hline \multicolumn{4}{c}{ Firms with below-median leverage } \\
\hline \multicolumn{2}{c}{ 2 or more } & \multicolumn{3}{c}{5 or more } \\
\hline 0.5523 & $(9.79)$ & 0.4762 & $(6.56)$ \\
0.0068 & $(0.70)$ & 0.0199 & $(1.12)$ \\
0.0269 & $(1.83)$ & 0.0176 & $(0.66)$ \\
-0.0009 & $(0.04)$ & -0.0557 & $(0.84)$
\end{tabular}

own segment's cash flow (0) /

own segment's assets ( 0 )

other segments' cash flow (0) I

other segments' assets ( 0 )

0.32

0.37

Adj-R-sq

751

179

For largest segments

Firms with below-median leverage

\begin{tabular}{cccc}
\hline \multicolumn{2}{c}{2 or more } & \multicolumn{2}{c}{5 or more } \\
\hline 0.4613 & $(4.05)$ & 0.5911 & $(6.30)$ \\
0.0535 & $(3.51)$ & 0.0697 & $(3.23)$ \\
0.0651 & $(2.45)$ & 0.0073 & $(0.35)$ \\
-0.0308 & $(1.17)$ & -0.1012 & $(2.63)$
\end{tabular}

For smallest segments

$\overline{\text { Firms with above-median leverage }}$

net capital expenditure (0) / own

segment's assets (-1)

\begin{tabular}{cccc}
\hline \multicolumn{2}{c}{2 or more } & \multicolumn{2}{c}{5 or more } \\
\hline 0.3927 & $(5.09)$ & 0.5182 & $(5.33)$
\end{tabular}

$$
\begin{array}{lr}
0.26 & 0.63 \\
751 & 179
\end{array}
$$

sales change (0) / net sales (-1)

own segment's cash flow (0) I

own segment's assets (0)

other segments' cash flow (0) I

other segments' assets ( 0 )

$0.0110 \quad(0.96) \quad 0.0168 \quad(1.02)$

$0.0611 \quad(3.58)-0.0195 \quad(0.61)$

$\begin{array}{llll}0.0322 & (1.12) & 0.0275 \quad(0.38)\end{array}$

For largest segments

Firms with above-median leverage

\begin{tabular}{llll}
\multicolumn{2}{c}{2 or more } & \multicolumn{2}{c}{5 or more } \\
\hline 0.5563 & $(5.16)$ & 0.5334 & $(5.53)$ \\
0.0081 & $(0.57)$ & 0.0142 & $(0.75)$ \\
0.0388 & $(2.35)$ & 0.0416 & $(1.82)$ \\
0.0253 & $(1.04)$ & -0.0118 & $(0.24)$
\end{tabular}

Adj-R-sq

0.23

0.33

0.37

0.34

Obs.

750

231

750

231

(Table is continued on the next page) 


\begin{tabular}{|c|c|c|c|c|c|c|c|c|}
\hline \multicolumn{9}{|l|}{ Table 6. (continued) } \\
\hline \multicolumn{9}{|c|}{ Panel B. Low Q firms. } \\
\hline \multirow{7}{*}{$\begin{array}{l}\text { net capital expenditure (0) / own } \\
\text { segment's assets }(-1) \\
\text { sales change }(0) \text { / net sales (-1) } \\
\text { own segment's cashflow }(0) \text { / own } \\
\text { segment's assets }(0) \\
\text { other segments' cashflow }(0) \text { / } \\
\text { other segment's assets }(0)\end{array}$} & \multirow{2}{*}{\multicolumn{4}{|c|}{$\frac{\text { For smallest segments }}{\text { Firms with below-median leverage }}$}} & \multirow{2}{*}{\multicolumn{4}{|c|}{$\frac{\text { For largest segments }}{\text { Firms with below-median leverage }}$}} \\
\hline & & & & & & & & \\
\hline & \multicolumn{2}{|c|}{2 or more } & \multicolumn{2}{|c|}{5 or more } & \multicolumn{2}{|c|}{2 or more } & \multicolumn{2}{|c|}{5 or more } \\
\hline & 0.3319 & $(5.74)$ & 0.2870 & (3.03) & 0.5120 & $(6.07)$ & 0.4742 & (3.84) \\
\hline & 0.0103 & $(0.84)$ & .0 .0162 & $(0.83)$ & 0.0179 & (1.11) & -0.0006 & $(0.02)$ \\
\hline & 0.0136 & $(0.84)$ & 0.0005 & $(0.02)$ & 0.1281 & $(3.86)$ & 0.1581 & (4.02) \\
\hline & 0.0628 & $(1.90)$ & 0.1813 & $(2.14)$ & 0.0570 & $(1.58)$ & 0.1107 & (1.64) \\
\hline Adj-R-sq & 0.19 & & 0.11 & & 0.36 & & 0.43 & \\
\hline \multirow[t]{4}{*}{ Obs. } & 753 & & 264 & & 753 & & 264 & \\
\hline & \multicolumn{4}{|c|}{ For smallest segments } & \multicolumn{4}{|c|}{ For largest segments } \\
\hline & \multirow{2}{*}{\multicolumn{4}{|c|}{$\begin{array}{c}\text { Firms with above-median leverage } \\
2 \text { or more } \\
5 \text { or more }\end{array}$}} & \multicolumn{4}{|c|}{ Firms with above-median leverage } \\
\hline & & & & & 2 or $m$ & & 5 or $\mathrm{m}$ & \\
\hline \multirow{4}{*}{$\begin{array}{l}\text { net capital expenditure (0) / own } \\
\text { segment's assets }(-1) \\
\text { sales change }(0) / \text { net sales }(-1) \\
\text { own segment's cashflow }(0) \text { / own } \\
\text { segment's assets }(0) \\
\text { other segments' cashflow (0) / } \\
\text { other segments' assets (0) }\end{array}$} & 0.3326 & (2.29) & 0.0950 & $(0.50)$ & 0.4856 & (3.56) & 0.6718 & $(6.20)$ \\
\hline & 0.0247 & $(1.64)$ & 0.0457 & $(2.00)$ & -0.0118 & $(1.35)$ & -0.0119 & $(0.90)$ \\
\hline & 0.0556 & $(2.84)$ & 0.0605 & (1.67) & 0.0354 & $(1.67)$ & 0.0504 & (1.85) \\
\hline & 0.0653 & (1.91) & 0.0708 & $(1.30)$ & -0.0281 & $(1.33)$ & -0.0141 & $(0.39)$ \\
\hline Adj-R-sq & 0.22 & & 0.15 & & 0.41 & & 0.56 & \\
\hline Obs. & 754 & & 314 & & 754 & & 314 & \\
\hline
\end{tabular}


in the relation between a division's investment and the cash flow of other divisions irrespective of leverage.

The results in table 6 do not distinguish between our various hypotheses. The bureaucratic rigidity hypothesis and the efficient internal capital market hypothesis both imply that investment of one division is more related to the cash flow of the other divisions when aggregate investment is more related to aggregate cash flow and the free cash flow hypothesis has no implications for this.

A firm can have an efficient internal capital market that takes resources from cash rich divisions with poor growth opportunities and funnel these resources towards divisions with better investment opportunities. With the free cash flow hypothesis, these resources are put to poor use in that shareholders would be better off if these resources were paid out to them in the form of dividends. With the Williamson version of the efficient internal capital markets hypothesis, these funds are put to good use, in that they fund profitable investments that would not take place in specialized firms because of capital markets imperfections. The efficient internal capital market therefore makes the prediction that firms with large divisions with poor growth opportunities will reallocate funds towards smaller divisions with better investment opportunities. We investigate this prediction in two steps. First, we address the issue of whether the smallest division grows more when the largest division has high cash flow but poor investment opportunities. Second, we investigate whether the smallest division receives more funds if it has greater investment opportunities. In the first test, we use as a proxy for the investment opportunities of the largest division the market-to-book ratio of the whole firm, assuming that the market-to-book ratio of the whole firm mostly reflects the investment opportunities of the largest division. In the second test, we use as a proxy for a division's investment opportunities the median market-to-book ratio of its industry. 
Table 7. Estimates of investment equations for high and low cash flow of largest segment.

Samples are divided according to the median cash flow of the largest segment. Panel $A$ provides estimates of investment equations for the smallest segment depending on whether the cash flow of the largest segment is high or low. Panel B provides estimates of investment equations for the largest segment. To identify the timing of the observation of the variables, we use periods 1,0 and -1 . The dependent variable is the segment's net capital expenditures in period 1 divided by the book value of the segment's assets at the end of period $0 . t$-statistics are in parentheses.

Panel A. The smallest segments.

\begin{tabular}{|c|c|c|c|c|}
\hline \multirow[b]{3}{*}{$\begin{array}{l}\text { net capital expenditure }(0) \text { / own } \\
\text { segment's assets }(-1)\end{array}$} & \multicolumn{2}{|c|}{$\begin{array}{c}\text { Below-median market to book ratio } \\
\text { and largest segment with below- } \\
\text { median cash flow } \\
\end{array}$} & \multicolumn{2}{|c|}{$\begin{array}{l}\text { Below-median market to book ratio } \\
\text { and largest segment with above- } \\
\text { median cash flow }\end{array}$} \\
\hline & 2 or more & 5 or more & 2 or more & 5 or more \\
\hline & $0.2373(1.66)$ & $0.0763 \quad(0.38)$ & 0.3866 & 0.2911 \\
\hline sales change $(0) /$ net sales $(-1)$ & $0.0302 \quad(1.97)$ & $0.0262 \quad(1.29)$ & 0.0047 & $-0.0042(-0.22)$ \\
\hline $\begin{array}{l}\text { own segment's cash flow }(0) / \\
\text { own segment's assets }(0)\end{array}$ & $0.0391 \quad(2.21)$ & 0.0421 & 0.0310 & 0.0325 \\
\hline $\begin{array}{l}\text { other segments' cash flow }(0) / \\
\text { other segments' assets }(0)\end{array}$ & $0.0778 \quad(2.38)$ & 0.0755 & 0.0324 & 0.1499 \\
\hline \multirow[t]{3}{*}{$\begin{array}{l}\text { Adj-R-sq } \\
\text { Obs. }\end{array}$} & $\begin{array}{r}0.13 \\
756\end{array}$ & $\begin{array}{l}0.07 \\
370\end{array}$ & $\begin{array}{r}0.28 \\
754\end{array}$ & $\begin{array}{r}0.18 \\
208\end{array}$ \\
\hline & \multicolumn{2}{|c|}{$\begin{array}{l}\text { Above-median market to book } \\
\text { ratio and largest segment with } \\
\text { below-median cash flow }\end{array}$} & \multicolumn{2}{|c|}{$\begin{array}{l}\text { Above-median market to book } \\
\text { ratio and largest segment with } \\
\text { above-median cash flow }\end{array}$} \\
\hline & 2 or more & 5 or more & 2 or more & 5 or more \\
\hline $\begin{array}{l}\text { net capital expenditure (0) / own } \\
\text { segment's assets }(-1)\end{array}$ & 0.3681 & 0.5607 & $0.5502(11.65)$ & 0.4437 \\
\hline sales change $(0) /$ net sales $(-1)$ & 0.0157 & 0.0228 & $0.0006 \quad(0.07)$ & 0.0063 \\
\hline $\begin{array}{l}\text { own segments' cash flow (0) / } \\
\text { own segments' assets (0) }\end{array}$ & 0.0262 & $-0.0281 \quad(-0.79)$ & $0.0548 \quad(3.45)$ & $0.0348 \quad(1.49)$ \\
\hline $\begin{array}{l}\text { other segments' cash flow }(0) / \\
\text { other segments' assets }(0)\end{array}$ & -0.0524 & $-0.0607 \quad(-0.88)$ & 0.0128 & 0.1004 \\
\hline Adj-R-sq & 0.18 & 0.34 & 0.38 & 0.44 \\
\hline Obs. & 755 & 225 & 749 & 185 \\
\hline
\end{tabular}




\begin{tabular}{|c|c|c|c|c|}
\hline \multicolumn{5}{|c|}{ Panel $B$. The largest segments. } \\
\hline \multirow{6}{*}{$\begin{array}{l}\text { net capital expenditure (0) / own } \\
\text { segment's assets }(-1) \\
\text { sales change }(0) / \text { net sales }(-1) \\
\text { own segment's cash flow }(0) / \\
\text { own segment's assets }(0) \\
\text { other segments' cash flow }(0) / \\
\text { other segments' assets }(0)\end{array}$} & \multicolumn{2}{|c|}{$\begin{array}{c}\text { Below-median market to book ratio } \\
\text { and largest segment with belowt } \\
\text { median cash flow }\end{array}$} & \multicolumn{2}{|c|}{$\begin{array}{c}\text { Below-median market to book ratio } \\
\text { and largest segment with above- } \\
\text { median cash flow }\end{array}$} \\
\hline & 2 or more & 5 or more & 2 or more & 5 or more \\
\hline & $0.5244 \quad(5.39)$ & $0.5210 \quad(4.35)$ & $0.4441 \quad(3.70)$ & $0.5732 \quad(8.31)$ \\
\hline & $-0.0089(-0.75)$ & $-0.0097 \quad(-0.47)$ & $0.0199 \quad(1.35)$ & $0.0180 \quad(0.96)$ \\
\hline & $0.0800 \quad(3.59)$ & $0.1190 \quad(3.72)$ & $0.0769 \quad(2.55)$ & $0.0809 \quad(3.20)$ \\
\hline & $0.0050 \quad(0.21)$ & $0.0183 \quad(0.36)$ & 0.0325 & $-0.0028 \quad(-0.09)$ \\
\hline Adj-R-sq & 0.42 & 0.47 & 0.31 & 0.50 \\
\hline \multirow[t]{3}{*}{ Obs. } & 756 & 370 & 754 & 208 \\
\hline & \multicolumn{2}{|c|}{$\begin{array}{l}\text { Above-median market to book } \\
\text { ratio and largest segment with } \\
\text { below-median cash flow }\end{array}$} & \multicolumn{2}{|c|}{$\begin{array}{l}\text { Above-median market to book } \\
\text { ratio and largest segment with } \\
\text { above-median cash flow }\end{array}$} \\
\hline & 2 or more & 5 or more & 2 or more & 5 or more \\
\hline $\begin{array}{l}\text { net capital expenditure }(0) \text { / own } \\
\text { segment's assets }(-1)\end{array}$ & $0.4548 \quad(5.11)$ & $0.5257 \quad(4.15)$ & $0.5844 \quad(4.38)$ & $0.5875 \quad(9.21)$ \\
\hline \multirow{3}{*}{$\begin{array}{l}\text { sales change }(0) / \text { net sales }(-1) \\
\text { own segment's cash flow }(0) / \\
\text { own segment's assets }(0) \\
\text { other segments' cash flow }(0) / \\
\text { other segments' assets }(0)\end{array}$} & $0.0156 \quad(1.22)$ & $0.0274 \quad(1.47)$ & $0.0300 \quad(1.68)$ & $0.0506 \quad(2.56)$ \\
\hline & $0.0371 \quad(1.61)$ & $-0.0037(-0.17)$ & $0.0551 \quad(2.46)$ & $0.0565 \quad(2.70)$ \\
\hline & $-0.0169(-0.54)$ & $-0.0333(-0.77)$ & $0.0096 \quad(0.49)$ & $-0.0414 \quad(-0.77)$ \\
\hline Adj-R-sq & $\begin{array}{l}0.20 \\
755\end{array}$ & 0.30 & 0.44 & 0.58 \\
\hline Obs. & 755 & 225 & 749 & 185 \\
\hline
\end{tabular}


Table 7 provides results for the sample split according to $q$ and according to the cash flow of the largest division. We divide firms according to the median cash flow of the largest segment. Panel A provides investment regressions for the smallest segment depending on whether the cash flow of the largest segment is high or low. We see that if Tobin's $q$ is low, the investment of the smallest segment depends positively on the cash flow of the other segments irrespective of whether the cash flow from the largest segment is large or small, but the coefficient on other segments' cash flow is significant only for the firms with two segments or more when the largest segment has belowmedian cash flow and for the firms with five segments or more when the largest segment has above-median cash flow. In contrast, when Tobin's $q$ is large, the cash flow of the other segments is irrelevant if the cash flow from the largest segment is below the sample median. However, in the case of firms with five segments or more where the largest segment has above-median cash flow, the coefficient on other segments' cash flow is a surprisingly large 0.10. Panel B provides results for the largest segment. We find there that whether the firm has a high or a low Tobin's $q$, the coefficient on other cash flow is insignificant in the largest segment regressions. In half the cases, the regression coefficient is negative but insignificant. Interestingly, the cash flow of the largest segment has a significant coefficient in all cases except when the largest segment has below-median cash flow and the firm has a high $\mathrm{q}$. These results offer mixed support for the free cash flow hypothesis: other cash flows matters more for low q firms but whether the largest segment has high or low cash flow does not seem to matter as much as the free cash low arguments would suggest.

Though we do not report the estimates here, we also investigated regressions for the largest and smallest segments when these segments are suffering losses. We found a significant coefficient on other segments' cash flow in the largest segment 
regression for firms with two or more segments but not in the regression for firms with five or more segments. For the firms with five or more segments, the regression coefficient is 0.069 , which is large compared to the other values reported in this paper, but the t-statistic is 1.25 . This regression has only 91 observations, however, which is the lowest sample size of regressions discussed in this paper. The coefficients on other segments' cash flow are 0.137 and 0.177 for the smallest segment regressions for firms with two segments or more and firms with five segments or more, and the tstatistics are, respectively, 3.27 and 3.06. Surprisingly, in these regressions the ownsegment cash flow has a marginally significant coefficient. This suggests that losses in the smallest segment slow down investment in that segment. There is no evidence that there is such an effect for the largest segment.

Our alternative approach to testing the efficient internal capital market view is to investigate whether a division grows more if it is in an industry that has better growth opportunities. We measure industry investment opportunities as follows. We start from the 3-digit SIC code of a segment. If there are five or more firms which have that 3-digit SIC code as their main SIC code, we take the median market-to-book of these five firms. If there are less than five firms in the 3-digit SIC code, we turn to the 2-digit code. We compute market-to-book deciles for each year in the sample. Having computed the market-to-book deciles, we then use an interactive dummy variable in two ways. First, we divide industry market-to-book each year into four quartiles. We then interact indicator variables for the second, third and fourth quartiles with other cash flows. These regressions are presented in panel $A$ of Table 8 . We find there that the industry investment opportunities have no significant effect for the second and third quartile. For the fourth quartile, they have a negative effect that is significant for firms with five segments or more. These results are not consistent with the efficient internal markets 


\section{Table 8. Estimates of investment equations controlling for industry growth opportunities}

Industry growth opportunities are mesured by the median market-to-book in the division's industry. Panel A provides estimates of investment equations for the smallest segment. Dummy variable D2 takes a value of 1 if the division's industry market to book is in 2nd quartile of industry market to book ratios that year, and so on. Panel B provides estimates of investment equations where the dummy variable Dm takes a value of 1 if the division's industry market to book is greater than the median industry market-to-book value in the same year. To identify the timing of the observation of the variables, we use periods 1,0 and -1 . The dependent variable is the segment's net capital expenditures in period 1 divided by the book value of the segment's assets at the end of period 0 . $t$-statistics are in parentheses.

Panel A. Regressions with quartile interactive dummy variables.

\begin{tabular}{|c|c|c|c|c|c|}
\hline \multirow{3}{*}{$\begin{array}{l}\text { net capital expenditure }(0) \text { / own } \\
\text { segment's assets }(-1)\end{array}$} & \multicolumn{3}{|c|}{ For smallest segments } & \multicolumn{2}{|c|}{ For largest segments } \\
\hline & 2 or $n$ & nore & 5 or more & 2 or more & 5 or more \\
\hline & 0.3940 & $(8.36)$ & $0.3285 \quad(3.99)$ & $0.5177(9.06)$ & $0.5492(7.69)$ \\
\hline sales change $(0) /$ net sales $(-1)$ & 0.0157 & (2.13) & $0.0229(1.70)$ & $0.0153 \quad(2.33)$ & $0.0184 \quad(1.66)$ \\
\hline $\begin{array}{l}\text { own segment's cashflow (0)/ own } \\
\text { segment's assets }(0)\end{array}$ & 0.0399 & $(4.75)$ & $0.0100 \quad(0.64)$ & $0.0666 \quad(5.60)$ & $0.0737 \quad(5.26)$ \\
\hline $\begin{array}{l}\text { other segment's cashflow }(0) / \\
\text { other segment's assets }(0)\end{array}$ & 0.0446 & $(3.42)$ & $0.0652(2.07)$ & $0.0101 \quad(0.83)$ & $-0.0028(-0.12)$ \\
\hline $\begin{array}{l}\text { D2* (other segment's cashflow }(0) \\
\text { / other segment's assets }(0) \text { ) }\end{array}$ & -0.0115 & $(-0.64)$ & $-0.0352(-1.16)$ & $-0.0188(-1.22)$ & $-0.0192(-0.76)$ \\
\hline $\begin{array}{l}\text { D3*(other segment's cashflow }(0) \\
\text { I other segment's assets }(0) \text { ) }\end{array}$ & -0.0079 & $(-0.67)$ & $-0.0138(-0.47)$ & $0.0155 \quad(1.01)$ & $-0.0382(-1.34)$ \\
\hline $\begin{array}{l}\text { D4*(other segment's cashflow }(0) \\
\text { / other segment's assets }(0))\end{array}$ & 0.0168 & $(0.32)$ & $-0.2564(-3.80)$ & $-0.0187(-0.46)$ & $-0.1911(-3.19)$ \\
\hline Adj-R-sq & 0.24 & & 0.21 & 0.35 & 0.47 \\
\hline Obs. & 3008 & & 988 & 3008 & 988 \\
\hline
\end{tabular}


Table 8. (continued)

Panel B.Regressions with median interactive dummy variables.

\begin{tabular}{|c|c|c|c|c|c|c|c|c|}
\hline \multirow[b]{3}{*}{$\begin{array}{l}\text { net capital expenditure (0) / own } \\
\text { segment's assets }(-1)\end{array}$} & \multicolumn{4}{|c|}{ For smallest segments } & \multicolumn{4}{|c|}{ For largest segments } \\
\hline & \multicolumn{2}{|c|}{2 or more } & \multicolumn{2}{|c|}{5 or more } & \multicolumn{2}{|c|}{2 or more } & \multicolumn{2}{|c|}{5 or more } \\
\hline & 0.3944 & $(8.36)$ & 0.3274 & (3.94) & 0.5171 & $(9.03)$ & 0.5509 & $(7.78)$ \\
\hline sales change $(0)$ / net sales $(-1)$ & 0.0158 & (2.13) & 0.0226 & $(1.67)$ & 0.0155 & (2.37) & 0.0181 & $(1.65)$ \\
\hline $\begin{array}{l}\text { own segment's cashflow (0) / own } \\
\text { segment's assets }(0)\end{array}$ & 0.0396 & $(4.72)$ & 0.0100 & $(0.64)$ & 0.0654 & $(5.63)$ & 0.0724 & $(5.21)$ \\
\hline $\begin{array}{l}\text { other segment's cashflow }(0) / \\
\text { other segment's assets }(0)\end{array}$ & 0.0413 & $(3.31)$ & 0.0568 & $(1.88)$ & 0.0063 & $(0.52)$ & -0.0069 & $(-0.31)$ \\
\hline $\begin{array}{l}\text { Dm* (other segment's cashflow (0) } \\
\text { / other segment's assets }(0) \text { ) }\end{array}$ & -0.0035 & $(-0.30)$ & -0.0176 & $(-0.66)$ & 0.0176 & $(1.20)$ & -0.0398 & $(-1.42)$ \\
\hline $\begin{array}{l}\text { Adj-R-sq } \\
\text { Obs }\end{array}$ & $\begin{array}{r}0.24 \\
3008\end{array}$ & & 0.21 & & 0.35 & & 0.47 & \\
\hline Obs. & & & 988 & & 3008 & & 988 & \\
\hline
\end{tabular}


hypothesis. With that hypothesis, one would expect the coefficient on the fourth quartile to be significantly positive. In panel $B$ of Table 8 , we estimate the same regressions with an indicator variable for industry investment opportunities above the sample median. It turns out that whether an industry has investment opportunities above or below the median has no impact on how much this segment invests.

As a last piece of evidence supportive of the bureaucratic rigidity hypothesis, we regressed the smallest segment's net capital expenditures normalized by segment assets on the firm's net capital expenditures normalized by the firm's book assets. For firms of five segments or more, the slope of this regression is 0.5122 with a t-statistic of 6.83. The adjusted R-squared of this regression is 0.13 . The investment rate of the firm therefore explains considerably more of the variation in the investment rate of the smallest segment than the segment's cash flow. This suggests that the smallest segment grows if the firm grows and stagnates otherwise.

\section{Section 5. Conclusion.}

In this paper, we explored the divisional investment policies of multi-division firms. Most of our results are for large diversified firms. Our results can be summarized as follows:

1. For the whole sample, the investment of the smallest division depends significantly on the cash flow of the other divisions. In contrast, the investment of the largest division depends on its own cash flow but not on the cash flow of the other divisions. 
2. The dependence of the smallest division's investment on the cash flow of other divisions exists only for firms with above-median leverage and firms with belowmedian market to book ratios.

3. There is no evidence that segments in industries with better investment opportunities receive relatively more of the firm's cash flow.

Our evidence is consistent with the view that the investment policy of divisions differs from the investment policy of similar stand-alone firms. Focusing on the smallest segment, we show that its investment is driven by the cash flow generated by other segments rather than by the prospects of its industry. The smallest segment invests more than stand-alone firms in the industry when the other segments do well and invests less when they do poorly. This suggests that investment in the smallest segment can be quite inefficient, being too little at times and too large at other times. Hence, even though our evidence is consistent with a strong role for an internal capital market in diversified firms, it appears that this internal capital market may lead to misallocation of resources. One hypothesis that can explain this result is that divisional shares of a firm's investment budget are sticky, so that when the investment budget falls because of lower cash flows at the firm level, divisional investment falls also. Overall, the evidence provides support for the bureaucratic rigidity hypothesis. We fail to find evidence supportive of the hypothesis that internal capital markets allocate funds efficiently. Our evidence is only partly consistent with the free cash flow hypothesis, in that we do not find strong support for the view that management expands the smallest division more when the largest division has poor investment opportunities and high cash flow. 


\section{References}

Berger, $P$. , and E. Ofek, 1995, Diversification's effect on firm value, Journal of Financial Economics 37, 39-65.

Bernanke, B., M. Gertler, and S. Gilchrist, 1993, The financial accelerator and the flight to quality, Unpublished working paper (Princeton University, Princeton, NJ).

Comment, R., and G.A. Jarrell, 1995, Corporate focus and stock returns, Journal of Financial Economics 37, 67-87.

Hubbard, R.G., 1995, Capital-market imperfections and investment, unpublished working paper, Columbia University.

Jensen, M.C., 1986, Agency costs of free cash flow, corporate finance and takeovers, American Economic Review 76, 323-339.

Kaplan, S.N., and L. Zingales, 1995, Do financing constraints explain why investment is correlated with cash flow?, Unpublished working paper (University of Chicago, Chicago, ILL).

Lamont, O., 1996, Cash flow and investment: Evidence from internal capital markets, Journal of Finance, forthcoming.

Lang, L.H.P., E. Ofek, and R. Stulz, 1995, Leverage, investment and growth, Journal of Financial Economics, forthcoming.

Lang, L.H.P., and R. Stulz, 1994, Tobin's q, corporate diversification, and firm performance, Journal of Political Economy 102, 1248-1280.

Lichtenberg, F.R., 1991, The managerial response to regulation of financial reporting for segments of a business enterprise, Journal of Regulatory Economics 3, 241249.

Lichtenberg, F.R., 1992, Industrial de-diversification and its consequences for productivity, Journal of Economic Behavior and Organization 18, 427-438.

Liebeskind, J., and Opler, T.C., 1992, The causes of corporate refocusing, unpublished working paper (Southern Methodist University, Dallas, TX).

Ravenscraft, D.J., and F.M. Scherer, 1987, Mergers, sell-offs, and economic efficiency, Brookings Institute, Washington, DC,

Smith, C.W. and R. Watts, 1992, The investment opportunity set and corporate financing, dividend and compensation policies, Journal of Financial Economics 32, 263-292. 
Stein, J.C., 1996, Internal capital markets and the competition for corporate resources, Journal of Finance, forthcoming.

Stulz, R.M., 1990, Managerial discretion and optimal financing policies, Journal of Financial Economics 26, 3-27.

Wernerfelt, B., and C.A. Montgomery, 1988, Tobin's $q$ and the importance of focus in firm performance, American Economic Review 78, 246-254.

Williamson, O.E., 1975, Markets and hierarchies: Analysis and antitrus implications, Collier McMillan Publishers, Inc. New York. 